\title{
Plant Physiology with Mathematic and Art Religion Engineering Science and Technology Approach
}

\author{
Tri Wahyu Agustina \\ Pendidikan IPA, Sekolah Pasca Sarjana, \\ Universitas Pendidikan Indonesia \\ Pendidikan Biologi, UIN Sunan Gunung Djati \\ Bandung, Indonesia \\ tri_agustina@student.upi.edu, \\ triwahyuagustina@uinsgd.ac.id \\ Nuryani Y. Rustaman \\ Pendidikan IPA, Sekolah Pasca Sarjana, \\ Universitas Pendidikan Indonesia \\ Bandung, Indonesia \\ nuryanirustaman@upi.edu
}

\author{
Riandi Riandi \\ Pendidikan IPA, Sekolah Pasca Sarjana, \\ Universitas Pendidikan Indonesia \\ Bandung, Indonesia \\ rian@upi.edu
}

\author{
Widi Purwianingsih \\ Pendidikan IPA, Sekolah Pasca Sarjana, \\ Universitas Pendidikan Indonesia \\ Bandung, Indonesia \\ widipurwianingsih@upi.edu
}

\begin{abstract}
This study aims to obtain a description of improving the students' skills to produce practical report products. Research on the study of Plant Physiology is the practice of making Compost and Aquaponic. The method was mixed embedded. The primary data was quantitative data in the form of result of product assessment of lab report. The supplementary data was qualitative data. It was obtained from interview and field notes. The research was done to one class consisting of 44 students in Biology Education Program. The sample was chosen purposively. Instruments are student worksheets, product assessment sheets and scoring, interview sheets, and field notes. Indicator of product rubric on aspects of Science, Technology, Religion, Engineering, Art and Math. The data analysis was done by counting the increase of score on the product of the report of Compost and Aquaponic laboratory. The results showed that students' ability in the aspects of Science did not increase, it is in contrast with the ability of students in aspects of Technology, Religion, Engineering, Art and Mathematics have increased. The implications of the research are the habit of using STREAM approach in other lectures.
\end{abstract}

Keywords- Product Assessment; Plant Physiology; Science Technology Religion Enjinering Art Mathematics

\section{INTRODUCTION}

College graduates have not been able to provide guarantees to obtain good jobs. BPS data in August 2017 showed an increase number in the unemployment rate of $0.14 \%$ compared to August 2016 [1]. The Government issued Presidential Regulation number 08 of 2012 regarding KKNI (Indonesia National Qualification Framework). KKNI is made to meet the needs of the world of work [2]. In KKNI there is a term of learning outcomes in accordance with the graduate profiles. Graduate Profile of Biology Education Program of UIN Sunan
Gunung Djati is Biology Educator for MA / SMA / SMK / MAK, Educational Researcher and Edupreneur [3].

One approach to learning (lectures) is done to prepare graduate profile through STREAM (Science-TechnologyReligion-Art-Mathematics) approach. STREAM is a development of STEM (Science-Technology-EngineeringMathematics). STEM has been developed in other countries, such as USA, Japan, Australia, Turkey, Malaysia [4-7]. Learning with STEM approach has been done through various researches in Indonesia. STREAM is a learning approach with the subject matter of Science that integrates the design of Engineering, the use of Technology, relating to Religion as well as meeting the aspects of Art and Mathematics. The Next Generation Science Standard issues a framework in studying science. This framework helps students build three dimensions in learning that is, scientific and engineering skills; crosscutting concepts in studying science and engineering; and an understanding of the core material in studying science [4].

Lectures with the STREAM approach follow the steps of engineering process design through the cycle that include: Ask, Imagine, Plan, Create, Improve back to ask and so on. Ask: starts with a question about the problem at hand. Imagine: think and use creative knowledge and ideas to solve problems. Plan: thinking about materials or resources to create technology. Create: create a design and follow the plan that has been made. Improve: analyze the technology made whether working or not, change the design to be better [7].

The Religion aspect is concerned with appreciating, living and practicing the religious teachings that are adhered to [8]. The religion adopted in this study is Islam, adapting to the location. In addition to the 2013 curriculum, the religion aspect is adapted to the development of UIN Sunan Gunung Djati Bandung curriculum. Tafsir (2013) states that UIN Sunan Gunung Djati Bandung develops knowledge that is 
guided by revelation. The term introduced is the paradigm of "Revelation Guides Science" [9, 10]. There is no dichotomy (contradictions) between religious science and general science. In other words, there is an attempt to integrate between the religious Science and the General Sciences [10]. Tafsir (2013) states Science is part of the common science. [9] Another view holds that religious values can be developed in Science by remembering the greatness of God. Humans are required to reflect on and pay attention to order, uniqueness, and admiration to the natural phenomena that it learns [11]. Thus, it is important to integrate between the Science of Religion and Science or integrate the Science of Religion and Science. Art is associated with creativity, innovation, design in making technologies and products produced [12, 13].

Lectures with the STREAM approach begin with topics that will be put forth as the problem. The problem used is Urban Farming. Currently, urban farming movement is becoming a trend in urban areas. Urban Agricultural Movement is aimed at overcoming the narrowing of agricultural land in urban areas. Bandung experienced problems of constriction of agricultural land [14]. Bandung City Government will continue the Urban Farming Movement [15]. Examples of urban agriculture applications are Composting and aquaponic production. Garbage in urban areas is mostly biological waste (organic waste). However, urban community involvement in waste management is lacking [16]. Urban waste can be used for composting [17]. Compost is used as a medium for urban farming. Meanwhile, the aquaponic is a combination of vegetable cultivation and fish cultivation $[18,19]$.

Biology Education of UIN Sunan Gunung Djati is located in Bandung. In the course of Plant Physiology with Urban Farming theme, students make Compost and aquaponic with STREAM approach. In Aquaponic manufacture, students cultivate kangkung because of its rapid growth [19]. Compost is used for kangkung growing media. Compost and Aquaponic Practicum is done on Plant Physiology lectures. Composting and Aquaponic are part of the science. Thus, the Religion aspect of the Compost and Aquaponic lab compounds with the paradigm of "Revelation Guides Science".

Product assessment is one of the suitable assessment tools used in the STREAM approach. In the product domain, expert assessment can be done with steps to create a quality product and product to be evaluated [20]. Product assessment used assessment rubric. The form of an analytic rubric with special criteria [21] to asses STREAM aspects. This study uses an analytic rubric to assess the STREAM aspect. The lab report is the main product of assessment.

In general, the objective is to obtain a general overview of student capability improvement in practical reporting products with the STREAM approach. The identification of the problem as the primary data: 10 Compost lab report, 20) Aquaponic lab report.

\section{RESEARCH METHOD}

\section{A. Research Design}

The research design was embedded mived design. It consist of various data from primary and secondary data. The primary data consist of qualitative and quantitative data. So does the secondary data [22]. The primary data was quantitative data in the form of result of product assessment of lab report. Supporting data in the form of qualitative data is the result of interviews and field notes. Source of data comes from sixth semester students of Biology Education. Sampling was taken by purposive sampling technique. The reason for purposive sampling because the number of male students in class A is more than class B. The number of male students in class A is 10 students and the number of female students is 39 people. Interviews were conducted on three upper group students, three middle school students and three lower group students. The field notes was based on students' lab activities.

\section{B. Research Instrument}

Instruments are student worksheets, product assessment sheets and scoring, interview sheets, and field notes. The product assessment framework includes the ability to answer the problem (Science), establish the theoretical basis (Science), estimate the fund (Mathematics), prepare tools and materials (Technology), design workflow drawings and tools (Engineering), calculate the needs of tools and materials), giving a religious view (Religion), documenting different physical forms of technology using materials available in nature (Technology and Art), identifying good compost features and good kale growth (Science), identifying the characteristics of kangkung (a kale-like plant) ready to harvest (Science), analyzing data and discussion (Science), packing compost and harvest kangkung (Art), summarizing the results of research (Science), identify kangkung ready to move to aquaponics (Science) and make a bibliography (Science). Interviews were conducted to reveal more deeply about student constraints during lab activities. The field notes contain things that are considered important during practicum activities. The field notes contain things that are considered important during practical activities.

The instrument has been validated by two colleagues from UIN Sunan Gunung Djati, a Religion Science expert from UIN Sunan Gunung Djati, an Assessment expert from the University of Education of Indonesia and three Biology Learning experts from Universitas Pendidikan Indonesia. Each aspect of the STREAM is assessed by a score ranging from 0 to 4 . The composting practical activities. A month later, Aquaponic lab activities were also undertaken. The data analysis was done by counting the increase of score on the product of the report of Compost and Aquaponic laboratory.

\section{RESULTS AND DISCUSSION}

\section{A. Results}

The primary data were quantitative data in the form of result of product assessment of lab report. Quantitative data was shown in table 1. In Table 1, the product assessment results indicate that in the Science aspect there is a decrease in 
score indicated by minus (-) while other aspects have increased score. The highest improvement was in engineering aspect.

TABLE I. PRODUCT ASSESSMENT RESULTS

\begin{tabular}{|l|l|l|l|l|}
\hline \multirow{2}{*}{ Aspects } & \multicolumn{4}{|c|}{ Product Assessment } \\
\cline { 2 - 5 } & Compost & Aquaponic & $\begin{array}{c}\text { Score } \\
\text { Difference }\end{array}$ & Description \\
\hline Science & 2.44 & 2.06 & -0.38 & $\begin{array}{c}\text { No } \\
\text { Improvement }\end{array}$ \\
\hline Technology & 0.00 & 1.71 & 1.71 & Improvement \\
\hline Religion & 2.25 & 2.71 & 0.46 & Improvement \\
\hline Engineering & 0.00 & 2.29 & 2.29 & Improvement \\
\hline Art & 1.25 & 1.93 & 0.68 & Improvement \\
\hline Mathematics & 0.75 & 1.21 & 0.46 & Improvement \\
\hline
\end{tabular}

The secondary data was from interviews and field notes the results of the interviews show the difficulties of students in finding sources of information on making Compost and aquaponic. Making compost and aquaponic are difficult for the student.

\section{B. Discussion}

Based on the analysis of product assessment data of practicum report shows an increase in aspects of Technology, Religion, Engineering, Art and Mathematics. The highest improvement was in engineering aspect. On the other hand, Science has a lowering score impact. The improvement was because the students are getting used to using STREAM approach in aquaponic lab activities. In compost lab, the students found it difficult since they are used to the previous lab module [22]. Before the lab begins, students make research proposals and are examined by researcher lecturers. The results of the examination from the lecturers of the researchers were subsequently revised to be reorganized into practical reports. Thus, an increase in scores on aspects of Technology, Religion, Engineering, Art and Mathematics.

In the aspect of Science there is a decrease in the score because the aspect of Science is something that is accustomed to other labs. Students are more focused on making practical reports on other aspects than Science. Science aspect is something new. The condition is evident with the results of performance assessment on the ability to design the technology design, compost product and the ability to pack compost is still lacking [23]. The ability to design compost technology is a technological aspect. The ability to package the compost categorized aspects of Art. Students are not familiar with STREAM approach

Based on the interviews, the students had difficulty in time management for the maintenance of kangkung and pest control that attacked the kangkung plant [23]. Based on the field notes, most of the students showed practicum activities that were inconsistent with the composting and aquaponic proposal plan. The product was the design of composting and aquaponic in lab report which is inconsistent with the predesigned proposal.
To further highlight the integration of STREAM, one example of the Crosscutting Concept Analysis STREAM analysis on composting in table II [23] was presented. Religion aspect viewed from core competence 1 in 2013 curriculum and "revelation guides science" paradigm

\section{TABLE II. CROSS-CUTTING CONCEPT ANALYSIS IN COMPOSTING THEORY}

\begin{tabular}{|c|c|}
\hline COMPOSTING & Process \\
\hline $\begin{array}{l}\text { 1) The type and } \\
\text { composition of } \\
\text { compost } \\
\text { materials } \\
\text { 2) Composting } \\
\text { techniques } \\
\text { 3) Success factors } \\
\text { of composting } \\
\text { 4he } \\
\text { characteristics } \\
\text { of good compost }\end{array}$ & $\begin{array}{l}\text { 1) Ask: identify the problem of composting } \\
\text { 2) Imagine: looking for composting problem } \\
\text { solution } \\
\text { 3) Plan: determining tools, materials, } \\
\text { designing composting technique design } \\
\text { 4) Create: compost according to the } \\
\text { predesigned plan. } \\
\text { 5) Improve: analyze and lead to the } \\
\text { composting result according to its function. } \\
\text { The compost product has been produced } \\
\text { according to the good standard } \\
\text { composting. If the compost product is not } \\
\text { suitable the redesigning is done to get } \\
\text { better results }\end{array}$ \\
\hline $\begin{array}{c}\text { Cross-Cutting } \\
\text { Concept }\end{array}$ & Description \\
\hline $\begin{array}{l}\text { 1) Cause and } \\
\text { effect: } \\
\text { mechanism and } \\
\text { explanation } \\
\text { 2) Scale, } \\
\text { proportion and } \\
\text { quantity } \\
\text { 3) Energy and } \\
\text { matter: Flows, } \\
\text { Cycles and } \\
\text { Conservation }\end{array}$ & $\begin{array}{l}\text { 1) Cause and effect: students are guided to } \\
\text { analyze causation, good compost can affect } \\
\text { plant growth. The next research is the } \\
\text { application of compost in seeding of } \\
\text { kangkung plants for aquaponic system. } \\
\text { 2) Scale, proportion and quantity: bridge } \\
\text { between science and mathematics in } \\
\text { determining composition of composting } \\
\text { materials and making EM }{ }_{4} \text { solutions } \\
\text { (Effective Mikroorganisme). } \\
\text { 3) Energy and matter: Flows, Cycles and } \\
\text { Conservation: composting requires energy } \\
\text { from the environment during fermentation. } \\
\text { The fermentation process in composting is } \\
\text { aerobic produces humus, carbon dioxide } \\
\text { and heat. }\end{array}$ \\
\hline Technology & $\begin{array}{c}\text { Religion core competence in } 2013 \\
\text { curriculum }\end{array}$ \\
\hline $\begin{array}{l}\text { 1) Using simple } \\
\text { tools in } \\
\text { composting } \\
\text { 2) Using a } \\
\text { container to } \\
\text { accommodate } \\
\text { the stirring of } \\
\text { compost } \\
\text { materials } \\
\text { (Composter) }\end{array}$ & $\begin{array}{l}\text { 1) Appreciate the teachings of Islam: caring } \\
\text { for the God-given natural resources of } \\
\text { caring for compost by placing in the shade, } \\
\text { observing it daily to avoid drought on } \\
\text { compost. When the compost dries, it is } \\
\text { added with water and stirred until evenly } \\
\text { distributed. Observation is done until the } \\
\text { compost becomes humus characterized by } \\
\text { color change to black (ground color), } \\
\text { crushed (crumb / dry structure) and } \\
\text { odorless } \\
\text { 2) Live the teachings of Islam: thanking God } \\
\text { for the available natural resources. The rest } \\
\text { of the organic waste and the presence of } \\
\text { microorganisms can be used for plant life } \\
\text { and fertilize the soil. } \\
\text { 3) Practicing the teachings of Islam: } \\
\text { composting to give good to the } \\
\text { environment as a form of worship that will } \\
\text { be rewarded by God }\end{array}$ \\
\hline
\end{tabular}


Table II. Cont.

\begin{tabular}{|c|c|}
\hline Engineering & Art \\
\hline $\begin{array}{l}\text { 1) Designing } \\
\text { composition of } \\
\text { compost } \\
\text { materials and } \\
\text { tools that are } \\
\text { available in the } \\
\text { surrounding } \\
\text { environment } \\
\text { 2) Creating a } \\
\text { container design } \\
\text { of composting } \\
\text { materials } \\
\text { (composter) }\end{array}$ & $\begin{array}{l}\text { 1) Creating innovative and creative } \\
\text { composting technology } \\
\text { 2) Packaging compostable products with great } \\
\text { attention to composting procedures }\end{array}$ \\
\hline \multicolumn{2}{|r|}{ Mathematics } \\
\hline \multicolumn{2}{|c|}{$\begin{array}{l}\text { 1)Calculating the required tools } \\
\text { 2) Determine the composition of compost materials that have been } \\
\text { used } \\
\text { 3)Calculating } \mathrm{EM}_{4} \\
\text { 4)Calculating the budget needed }\end{array}$} \\
\hline
\end{tabular}

(Source: Agustina et. al., 2017)

On the aspect of religion with the paradigm "Revelation Guides Science" that on making compost utilize microorganisms. Composting is one of aerobic decomposition techniques of decaying organic material (biological) into a ground flower product (humus) [17, 24]. Microorganisms involved in composting such as Actinomycetes, fungi, protozoa [24]. One of the verses of the holy Qur'an is in AzZumar verse 21 states that God regulates the cycle of organic matter or the decomposition / destruction of organic matter [9]. The Az-Zumar, verse 21, translation said that : Do you not see that Allah sends down rain from the sky and makes it flow as springs [and rivers] in the earth; then He produces thereby crops of varying colors; then they dry and you see them turned yellow; then He makes them [scattered] debris. Indeed in that is a reminder for those of understanding. On the translation, the statement "...then they dry and you see them turned yellow; then He makes them [scattered] debris. Science explains that the symptoms of drought-subsequent plants are yellowish and further destroyed is the process of decomposition (decomposition of organic matter) by bacterial microorganisms and fungi.

Compost uses organic matter as a carbon source, i.e from the remnants of decomposing plant waste. One method of composting with the accumulation of organic materials on the ground [24]. Microorganisms can decompose organic materials from the soil. It is relevant to Surrah Taha verse 6: To Him belongs what is in the heavens and what is on the earth and what is between them and what is under the soil. In the verse there is a sentence "...what is on the earth" shows that God created everything both in heaven and in the earth. Sources of microorganisms on composting can come from within the soil capable of decomposing organic matter into compost. God Almighty who has created microorganisms for human use in composting Therefore, the composting process is consistent with the holy qur'an.

In the paradigm of "Revelation Guides Science" on Aquaponic manufacture. Aquaponic is a combination of aquaculture and hydroponics. Plants and fish are organic The aquaponic system is environmentally friendly [19]. A good Muslim always keeps the environment as stated in Huud's letter: 117: And your Lord would not have destroyed the cities unjustly while their people were reformers. The statement said that "... their people were reformers" shows that God as the Supreme Governor commands the human to do good. One form of goodness is to maintain the environment by using Aquaponic. Aquaponic can grow plants. Allah SWT on Qur'an surrah Abasa verses 26-27 states: Then We broke open the earth, splitting [it with sprouts], And caused to grow within it grain Allah Almighty who has given ability to the plant for growth and development [25]. Therefore, the aquaponic process is consistent with the holy qur'an.

\section{CONCLUSION}

The conclusion is that students' ability has improved in aspects of Technology, Religion, Art, Engineering, and Mathematics. The students' ability in the Science aspect has not improved. The research recommendation is that there should be a habit of using STREAM approach in other lectures. STREAM approach may support the graduate profile.

\section{ACKNOWLEDGEMENT}

The Authors expresses their best gratitude to the Directorate General of Islamic College of the Ministry of Religious Affairs of the Republic of Indonesia who has provided financial support for the completion of this research.

\section{REFERENCES}

[1] P. A. Julianto, “Agustus 2017, Jumlah Pengangguran Naik Menjadi 7,04 Juta Orang" [Online available: http://ekonomi.kompas.com/read/2017/11/06, 2017].

[2] Direktorat Pembelajaran dan Kemahasiswaan, "Buku Kurikulum Pendidikan Tinggi",. Jakarta: Direktorat Jenderal Kementrian Pendidikan Tinggi Kementrian Pendidikan dan Kebudayaan, 2014.

[3] Pendidikan Biologi, "Kerangka Kualifikasi Nasional Indonesia dan Profil Lulusan Pendidikan Biologi”, Unpublished.

[4] Bybee, "The Next Generation Science Standards and The Life Sciences", Washington: The National Academic Press, 2013.

[5] N.M. Bahri, E. Suryawati, and K. Osman, "Students Biotechnology Literacy: The Pillars of Stem Education in Malaysia", International Society of Educational Research. vol. 10 (3), pp. 195-207, 2014.

[6] Ceylan and Z. Ozdilek, "Improving a Sample Lessons Plan for Secondary Sciences Courses within the STEM Education", ProcediaSocial and Behavioral Sciences, no. 177, pp. 223-228, 2014.

[7] C. Rosicka, "Translating STEM Education Research into Practice", Victoria: Australian Council for Educational Research, 2016.

[8] Kementrian Pendidikan dan Kebudayaan, "Panduan Penilaian Pencapaian Kompetensi Peserta Didik Sekolah Menengah Pertama”, Jakarta: Direktorat Pembinaan Sekolah Pertama, 2014.

[9] H. M. Subandi, "Mikrobiologi, Perkembangan, Kajian, dan Pengamatan dalam Perspektif Islam", Bandung: PT. Remaja Rosdakarya, 2010.

[10] N.F. Natsir, "Paradigma Wahyu Memandu Ilmu dalam Pembidangan Ilmu-Ilmu Keislaman. [Online available: http://www.uinsgd.ac.id/front/detail/mengenal_tokoh/nanat-fatah-natsir, 2013].

[11] S. Yudianto, "Manajemen Alam (Sains) Sumber Pendidikan Nilai", Bandung: Mughni Sejahtera, 2005.

[12] A. D. Wijaya, N. Karmila, dan M.R. Amalia , "Implementasi Pembelajaran Berbasis STEAM (Science, Technology, Engineering, Art, 
Mathematics) pada Kurikulum Indonesia “, Prosiding Seminar Nasional Fisika dan Aplikasinya. Universitas Padjadjaran, November 2015.

[13] A.T. Oner, S.B Nite, R.M. Capraro, and M.M. Capraro, "From STEM to STEAM: Students' Beliefs About The Use of Their Creativity" The STEAM Journal.vol 2, pp: 1-14, 2016.

[14] Dinas Pertanian dan Ketahanan, 2012. "Rencana Strategis Dinas Pertanian dan Ketahanan Pangan Kota Bandung", [Online available: https://portal.bandung.go.id/storage/konten-

lama/download/Transparansi/Perencanaan/Rencana_Strategis_Dinas_Pe rtanian_dan_Ketahanan_Pangan_2009-2013.pdf, 2012].

[15] Parno, 2017. "Bandung Teruskan Program Gerakan Urban Farming", [Online available: http:jabarprov.go.id/index.php/news/2017/01/10, 2017].

[16] I. Irawati, Salahudin dan Selvianti, "Konsep Industri Sampah (KIS) sebagai Konsep Pengelolaan Sampah Perkotaan di Kota Bandung". Prosiding Seminar Nasional Pendidikan Lingkungan Hidup. Malang: Universitas Negeri Malang. pp 214-227, 2009.

[17] E. Damanhuri, dan T. Padmi, "Diktat Kuliah: Pengelolaan Sampah", Bandung”, Bandung: Institut Teknologi Bandung, 2010.

[18] K. Mayasari, "Konsep Urban Farming sebagai Solusi Kota Hijau", [Online

available: http:jakarta.litbang.pertanian.go.id/ind.index.php/publikasi, 2016].
[19] B. Sani, "Asyiknya Akuaponik untuk Hobi dan Bisnis", Jakarta: C.V. Solusi Distribusi, 2016.

[20] R. J. Stiggins, "Student-Centered Classroom Assesment", New York: Macmillan College Publishing Company, 1994.

[21] A. Zainul, “Alternative Assesment”, Jakarta: Universitas Terbuka, 2001.

[22] J.W. Creswell, "Educational Research: Planning, Conducting, and Evaluating Quantitative and Qualitative Research', Boston: Pearson, 2012.

[23] T W Agustina, N Y Rustaman, Riandi and W Purwianingsih, "The Learning of Compost Practice in University", Journal of Physic: Conference vol. 895 [ IOP Publisihing, doi:10.1088/17426596/895/1/012128, 2017].

[24] Sardjoko, "Bioteknologi Latar Belakang dan Beberapa Penerapannya", Jakarta: PT Gramedia Pustaka Utama, 1991.

[25] H. Thalbah, A.M. Zindani A M, dkk "Ensiklopedia Mukjizat Al Quran dan Hadis", Jakarta: PT. Sapta Sentosa, 2008. 